\title{
Penguatan Pemahaman Perpajakan Terkait Pengadaan Barang dan Jasa pada Pemerintah Desa di Kecamatan Sumbang Kabupaten Banyumas
}

\author{
Christina Tri Setyorini ${ }^{1 *}$, Dewi Susilowati ${ }^{1}$ \\ ${ }^{1}$ Jurusan Akuntansi, Fakultas Ekonomi dan Bisnis Universitas Jenderal Soedirman, \\ Jl. HR Bunyamin Kotak Pos 708 Purwokerto, Indonesia \\ *Penulis korespondensi, email: christina.setyorini@unsoed.ac.id
}

\section{Submit : \\ 23 Juni 2020 \\ Diterima: \\ 18 Agustus 2020 \\ Terbit:}

30 Agustus 2020

\begin{abstract}
Abstrak. Pelaksanaan pengabdian pada masyarakat dilaksanakan di Kecamatan Sumbang, Kabupaten Banyumas, Propinsi Jawa Tengah dalam bentuk sosialisasi dan diskusi permasalahan pajak di pemerintah Desa Tujuan pengabdian pada masyarakat adalah untuk meningkatkan pemahaman aparatur Desa tentang perpajakan terkait Pengadaan Barang dan Jasa dalam pelaksanaan pembangunan swakelola. Manfaat yang diharapkan dari kegiatan sosialisasi serta diskusi permasalahan pajak yang dihadapi aparatur Desa dapat memberikan penguatan pemahaman, sehingga dapat membantu memecahkan permasalahan yang selama ini mereka hadapi. Partisipan dari kegiatan pengabdian pada masyarakat ini adalah aparatur Desa yang terkait dengan masalah pajak, yaitu para kaur keuangan (Bendahara) dan sekretaris Desa, sebagai koordinator tugas dan fungsi kepala urusan di Kecamatan Sumbang yang berjumlah 19 Desa, sehingga berjumlah sekitar 25 orang. Evaluasi untuk pelaksanaan kegiatan pengabdian pada masyarakat adalah aspek penguasaan pengetahuan dan aplikasi peraturan perpajakan dalam konteks dana desa.
\end{abstract}

Kata Kunci: dana desa, pajak, pengadaan barang dan jasa, swakelola 


\section{PENDAHULUAN}

Sumbang merupakan salah satu dari dua puluh tujuh kecamatan di kabupaten Banyumas, yang terletak sekitar $12 \mathrm{~km}$ di ujung timur laut wilayah Banyumas, dan berbatasan langsung dengan kabupaten Purbalingga di sebelah timur, sebelah barat dibatasi oleh kali Pelus yang merupakan batas barat dengan kecamatan Baturaden, sebelah selatan berbatasan dengan kecamatan Kembaran, dan sebelah utara lahan perhutani dan gunung Slamet. Sumbang merupakan salah satu kecamatan di Kabupaten Banyumas yang mempunyai jumlah desa terbanyak ke dua setelah kecamatan Cilongok, dengan jumlah sampai sembilan belas desa sebetulnya mempunyai potensi alam dan sumber daya manusia yang cukup besar, bentang alam yang khas dan sangat potensial untuk dikembangkan menjadi daerah tujuan wisata alternatif setelah Baturaden.

Pendapatan penduduk terutama dari pertanian. Peternakan ayam di sumbang terletak di desa Banteran dan Gandatapa. Tanah sawah dan perladangan di kecamatan Sumbang sangat mendukung agrobisnis. Di bawah lereng selatan Gunung Slamet terdapat sumber pengairan yang cukup untuk pertanian dan perikanan. Industri mebel yang tersebar di banyak desa terutama Desa Banjarsari Wetan. Fasilitas pendidikan tersedia mulai TK, 34 Sekolah Dasar Negeri dan 1 Madrasah intidaiyah, 4 SMP Negeri, 2 SMP Swasta, 2 MTs dan 2 SMK. Fasilitas kesehatan terdapat 3 puskesma dan 1 klinik umum. Mayoritas penduduknya beragama Islam dan di tiap desa terdapat masjid dan musala. Selain itu terdapat 1 gereja Kristen Jawa di Karanggintung. Objek wisata di kecamatan Sumbang meliputi Curug Ceheng, Wisata Budaya (Ebeg, Lengger, Biaksi dll), Wisata Sejarah (Petilasan dll).

Pembangunan daerah diperkuat dengan adanya Dana Desa yang dikucurkan Pemerintah Pusat ke seluruh desa di Indonesia. Optimalisasi penyerapannya diatur melalui Peraturan Menteri No.16 Tahun 2018 tentang Prioritas Penggunaan Dana Desa untuk meminimalisir terjadinya penyelewengan. Permen tersebut diterbitkan oleh Menteri Desa, Pembangunan Daerah Tertinggal, dan Transmigrasi Republik Indonesia yang dalam pasal 4, ayat 1 adalah penggunaan dana Desa diprioritaskan untuk membiayai pelaksanaan program dan kegiatan di bidang pembangunan Desa dan pemberdayaan masyarakat desa. Pada ayat 2 mengungkapkan bahwa prioritas penggunaan Dana Desa sebagaimana dimaksud pada ayat (1) dapat digunakan untuk membiayai pelaksanaan program dan kegiatan prioritas yang bersifat lintas bidang. Ayat 3 mengaitkan ayat (1) dan (2) tentang prioritas penggunaan Dana Desa diharapkan dapat memberikan manfaat sebesar-besarnya bagi masyarakat Desa berupa peningkatan kualitas hidup, peningkatan kesejahteraan dan penanggulangan kemiskinan serta peningkatan pelayanan public di tingkat Desa. Penekanannya bergeser dari pembangunan yang bersifat fisik ke peningkatan kualitas sumber daya manusia yang berada di Desa.

Pasal 5 mengungkapkan prioritas penggunaan dana Desa untuk peningkatan kualitas hidup masyarakat Desa dilakukan melalui pengadaan pembangunan, pengembangan, pemeliharaan harta sarana dan prasarana untuk memenuhi kebutuhan, seperti fasilitas transportasi, energi, bidang kesehatan masyarakat, Pendidikan dan kebudayaan, ekonomi dan lain sebagainya. Usaha peningkatan pelayanan publik di tingkat desa dijelaskan pada pasal 6 Permen No.16 Tahun 2018, yaitu penyediaan air bersih dan sanitasi, pemberian makan tambahan untuk bayi dan balita, hingga pelatihan pemantauan 
perkembangan kesehatan ibu hamil atau ibu menyusui serta beberapa kegiatan kesehatan lainnya. Bichler (2013) menyatakan bahwa otoritas pemerintah pada dasarnya bertanggung jawab mengatur proses pengadaan barang dan jasa publik terutama pada otoritas pemerintah daerah yang lebih rendah dengan mengamankan sumber daya publik dan mempromosikan pembangunan sosial-ekonomi.

Program-program yang telah ditetapkan dalam pelaksanaannya membutuhkan dana untuk pengadaan barang dan jasa. Sumber dana yang utama adalah dana desa. Aparatur Desa harus memahami tupoksi mereka dengan baik agar dapat melaksanakan program-program yang telah disepakati bersama masyarakat desa. Permasalahan adakalanya timbul saat pelaksaaan kegiatan yang menggunakan dana desa. Hal ini terkait dengan kesiapan dan pemahaman para aparatur desa dalam mengelola dana desa. Pada pelaksanaan pengadaan barang dan jasa di desa juga menjadi permasalahan yang krusial. Ki-moon (2012) menyatakan hal yang sama bahwa sebagian besar pimpinan daerah dan aparatur desa hampir sebagian besar memiliki pengetahuan dan pengalaman yang rendah tentang proses pengadaan barang dan jasa. Hal tersebut berpotensi menjadi penyebab terjadinya korupsi dan pemborosan. Pengadaan barang dan jasa publik memiliki implikasi ekonomi dan politik yang penting karena membelanjakan dana publik, sehingga memastikan bahwa prosedur pengadaan dilaksanakan secara ekonomis dan efisien menjadi sangat penting (Huka et al, 2014). Namundemikian, bagi sebagian besar negara berkembang, sedang melakukan langkah-langkah untuk mereformasi sistem pengadaan publik yang masih diselimuti oleh kerahasiaan, ketidakefisienan, dan korupsi. Lebih buruk lagi, dalam semua kasus ini, sejumlah besar sumber daya publik menjadi terbuang sia-sia (Odhiambo, 2003).

Pengadaan barang dan jasa di desa juga menghadapi permasalahan kualitas sumber daya manusia terkait pembahaman pajak atas pengadaan barang dan jasa. Pajak menjadi hal yang sangat krusial ketika pemahaman aparatur desa tentang pajak sangat minim. Bendaharawan merupakan Wajib Pajak yang diberi kewenangan sebagai pemotong dan pemungut pajak oleh Undang-Undang Perpajakan, termasuk di dalamnya adalah Bendahara Desa. Namun demikian, kepatuhan bendahara desa dalam melaksanakan kewajiban perpajakan masih rendah meskipun transfer Pemerintah Pusat untuk daerah dan Dana Desa terus meningkat secara signifikan,tetapi penerimaan pajak dari aktivitas di daerah masih rendah, berada dikisaran 3,6\% (Katadata 2017). Saad (2014) menyatakan bahwa bahwa wajib pajak yang memiliki pengetahuan pajak yang rendah akan menganggap bahwa sistem pajak merupakan suatu hal yang kompleks dipandang sebagai penyebab perilaku ketidakpatuhan wajib pajak. Pemahaman pajak tidak terbatas hanya mengenal istilah dan tarifnya, tetapi diperlukan pengetahuan dan aplikasi penghitungannya terkait dengan penggunaan dana desa. Atas dasar hasil wawancara awal, kemudian pembahasan dalam Focus Group Discussion (FGD), diperoleh suatu simpulan bahwa aparatur desa, khususnya sekretaris desa dan kaur keuangan (bendahara), memerlukan penyuluhan atau sosialisasi pajak untuk meningkatkan kemampuan pemahaman terkait pajak pengadaan barang dan jasa.

\section{METODE}

Terdapat beberapa tahapan dalam pelaksanaan pengabdian masyarakat ini. Tahapan pelaksanaan pengabdian masyarakat ini dapat ditunjukkan pada Gambar 1. 


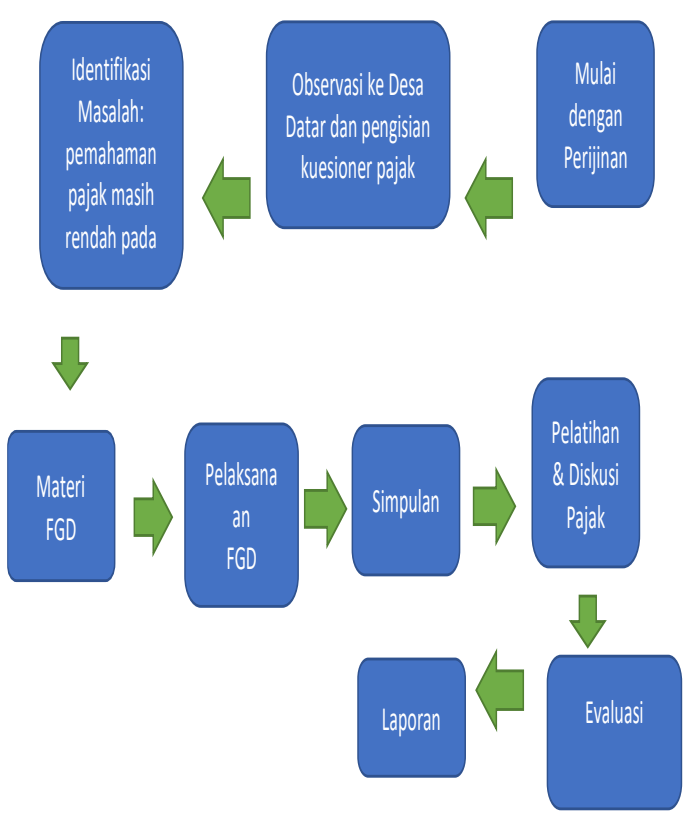

Gambar 1. Metode Pelaksanaan Pelatihan Pajak

Metode pelaksanaan kegiatan dilakukan melalui beberapa tahap, yaitu tahap pertama adalah mengurus perijinan, kemudian melakukan observasi dan penyebaran kuesioner untuk mengidentifikasi permasalahan utama mitra. Berdasar hasil observasi lapangan dan penyebaran kuesioner maka dapat teridentifikasi masalah di desa terkait pajak pengadaan barang dan jasa yaitu pengetahuan terkait pajak pengadaan barang dan jasa di Kecamatan Sumbang masih rendah hal ini terungkap dari hasil wawancara pendahuluan dengan aparatur desa Datar yang terdiri dari Kepala Desa, Sekretaris Desa, Kasi Pemerintahan, dan Kaur Pembangunan serta Kasi Kesejahteraan yang semuanya menyatakan kurang mengetahui peraturan perpajakan terkait pengadaan barang dan jasa. Mereka hanya mengikuti siskeudes yang telah menetapkan pajak keseluruhan sebesar $11,5 \%$. Padahal pengadaan barang dan jasa di desa mempunyai tarif PPN untuk jenis barang yang berbeda-beda. Hal ini juga didukung dengan hasil pengisian kuesioner dengan pertanyaan terbuka yang disebarkan pada 19 desa di Kecamatan Sumbang dengan total 89 kuesioner, menunjukkan bahwa rata- rata hanya $40 \%$ dari seluruh pertanyaan terkait pajak yang dapat dijawab oleh 89 apartur desa

Tahap kedua dilakukan setelah teridentidikasi masalah yang ada maka dilakukan FGD yang dihadiri oleh aparatur desa yang terdiri dari Kepala Desa,Sekretaris Desa, Kaur Keuangan, Kasi Pemerintahan, Kasi Kesejahteraan dan pendamping desa perwakilan dari desa yang ada di Kecamatan Sumbang. Sebelum dilakukan FGD maka terlebih dahulu disusun materi FGD berupa daftar pertanyaan yang terkait dengan pengadaan barang dan jasa dan pajak untuk masing masing aparatur desa. Tahap selanjutnya adalah menyimpulkan hasil pemetaan masalah yang diperolah dari FGD. Berdasar FGD yang telah dilakukan dapat disimpulkan bahwa sebagian besar aparatur desa masih belum memahami penghitungan tarif pajak pengadaan barang dan jasa. Mekanisme pengenaan pajak juga belum banyak dipahami, terlebih jenis pajak pada pengadaan barang dan jasa secara swakelola.

Pada tahap berikutnya modul dipersiapkan sebagai bahan referensi peserta sosialisasi atau pelatihan, agar materi yang disampaikan terarah dengan baik.Modul disiapkan dengan menekankan pada penghitungan pajak atas pengadaan barang dan jasa. Setelah materi disampaikan melalui pelatihan, peserta diberikan kesempatan untuk berdiskusi dengan nara sumber. Peserta dapat menanyakan tentang materi yang sudah disampaikan maupun kasuskasus yang mereka temui di desa mereka. Evaluasi akhir digunakan untuk mengetahui hasil pengabdian masyarakat yang telah dilakukan.

\section{HASIL DAN PEMBAHASAN}

Pengabdian kepada masyarakat oleh tim pengabdian masyarakat di Desa Datar Kecamatan Sumbang yang dihadiri oleh 28 peserta yang mewakili sekretaris desa dan kaur keuangan 
(bendahara) dari 19 Desa di Kecamatan Sumbang dilaksanakan pada tanggal 22 Agustus 2019. Pengabdian masyarakat ini dilaksanakan atas dasar hasil analisis kebutuhan pemecahan masalah yang dihadapi aparatur desa sehubungan dengan pengelolaan dana Desa, khususnya dalam kegiatan pengadaan barang dan jasa terkait perpajakan.

Pada tahap identifikasi masalah melalui wawancara di Desa Datar diperoleh simpulan bahwa hampir semua aparatur desa tidak memahami masalah perpajakan terkait dengan penggunaan dana Desa. Dana Desa digunakan untuk seluruh dana yang diterima desa dan menjadi sumber pendapatan Desa di APBDesa. Penggalian lebih mendalam tentang masalah pajak ini dibawa ke Focus Group Discussion (FGD) untuk diperoleh simpulan yang lebih spesifik. Hasil evaluasi pajak Dana Desa, diperoleh simpulan bahwa sebagian besar desa belum sepenuhnya melaksanakan kewajiban pajak atau belum optimal pajaknya berdasarkan pada besar pajak dibanding pagu atau jenis-jens kegiatan sebagai pelaksanaan APBDesa atau Tax Collection pajak desa sebesar $11,5 \%$, sesuai dengan yang ditetapkan dalam siskeudes. Pembakal dan Bendahara Desa belum memahami sepenuhnya Sosialisasi dilakukan dengan menjelaskan terkait kewajiban perpajakan dan manfaat pajak yang dibanyarkan masyarakat, kemudian potensi pajak yang mungkin dikenakan atas dana desa termasuk pajak dana desa pada khususnya. Sosialisasi dilakukan dalam 4 tahap. Pada tahap pertama dijelaskan tentang perpajakan secara umum termasuk dalam hal ini penjelasan terkait NPWP, PTKP dan e filling.

Pada tahap pertama ini direspon oleh peserta dengan antusias. Banyak dari peserta yang tidak mengetahui pentingnya NPWP dan belum mengenal istilah PTKP. Pertanyaan yang banyak disampaikan peserta adalah mereka belum mengetahui cara penghitungan PTKP.

Tahap kedua sosialisasi dilakukan dengan memaparkan tentang pajak penghasilan no 21, 22 dan 23. PPh pasal 21: Pajak yang dipotong atas pembayaran berupa gaji, upah, honorarium, dan pembayaran lain yang diterima oleh Orang Pribadi (OP). Penghitungan pajak penghasilan Pasal 22, Pajak yang dipungut dari Pengusaha/Toko atas pembayaran atas pembelian barang dengan nilai pembelian diatas Rp 2.000.000, tidak terpecah-pecah. Tarif pajak sebesar $1,5 \%$ dari harga pembelian tidak termasuk PPN. PPh Pasal 23: Pajak yang dipotong dari penghasilan yang diterima rekanan atas sewa (tidak termasuk sewa tanah dan atau bangunan), serta imbalan jasa manajemen, jasa teknik, jasa konsultan dan jasa lain. tarif pajak sebesar 2\% dari jumlah bruto. PPh Pasal 4 Ayat 2: Pajak yang dipotong atas pembayaran Jasa Konstruksi, dalam hal ini terdapat 2 perbedaan: Perencana Konstruksi dan Pengawas Konstruksi dengan tarif $4 \%$ bagi yang memiliki kualifikasi dan $6 \%$ bagi yang tidak memiliki kualifikasi;Pelaksana konstruksi dengan tarif $2 \%$ yang memiliki kualifikasi kecil, 4\% yang tidak memiliki kualifikasi dan $3 \%$ bagi yang dilakukan oleh penyedia jasa. Pada tahap ini yang menjadi ketidakpaahaman peserta adalah saat penghitungan PPh pasal 21. Kemudian setelah diberikan penjelasan dan contoh penghitungan menjadi paham.

Tahap ketiga adalah penjelasan terkait PPN ecara umum atas setiap transaksi pembelian barang dan perolehan jasa dari pihak ketiga/rekanan yang dibayar oleh bendahara harus dipungut PPN dengan tarif $10 \%$ dari Dasar Pengenaan Pajak yaitu harga jual untuk barang dan harga penggantian untuk jasa pada saat pembayaran dengan cara pemotongan secara langsung dari tagihan PKP Rekanan 
pemerintah, misalkan pemungutan PPN atas: pembelian alat tulis kantor;pembelian seragam untuk keperluan dinas; pembelian komputer; pembelian bahan/material bangunan; perolehan jasa pemasangan jaringan komputer; perolehanjasa perawatan AC; perolehan jasa atas perbaikan peralatan kantor perolehan atas sewa gedung.kantor/tanah. Pemungutan atas pembelian barang atau jasa yang jumlahnya diatas Rp. 1.000.000,00 tidak merupakan pembayaran yang terpecah-pecah dengan besaran pajak $10 \%$ dari pembelian barang atau jasa. Pengentahuan tentang pajak atas dana desa ini harus dikuasai betul oleh Bendahara Desa agar tidak terjadi kesalahan dalam penggunaan dana desa dan dapat dipertanggungjawabkan sesua aturan main yang sudah ditetapkan.

Tahap selanjutnya adalah tahap evaluasi peserta sosialisasi yang dilakukan pada seluruh aparatur desa yang menjadi peserta sosialisasi. Evaluasi dilakukan dengan memberikan daftar pertanyaan yang sama seperti saat observasi dilakukan. Berdasar hasil sebelum dilakukan sosialisasi pertanyaan terkait pajak atas dana desa dan pajak atas pengadaan barang dan jasa pada khususnya mengalami kenaikan yang cukup tinggi dari $40 \%$ menjadi $84 \%$. Demhan demikian terbukti bahwa sosialisasi berdampak signifikan dalam peningkatan pengetahuan aparatur desa terkait pajak dana desa. Sosialisasi yang dilakukan secara terus menerus akan dapat menghasilkan pemahaman yang tinggi terkait dengan penghitungan pajak dana desa serta pajak atas pengadaan barang dan jasa pada khususnya. Berikut adalah foto kegiatan yang dilakukan pada pelatihan pajak dana desa.

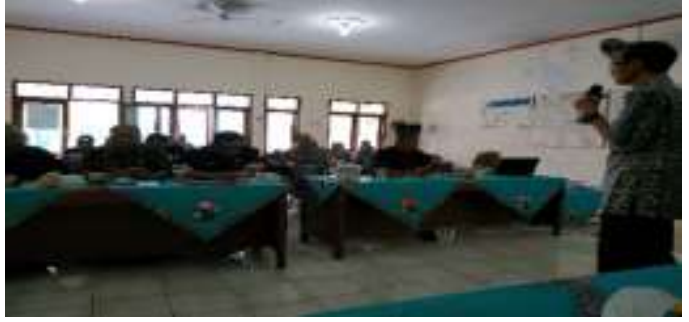

Gambar 1. Paparan materi pajak atas dana desa: PPh pasal 21, 22,23 dan PPN

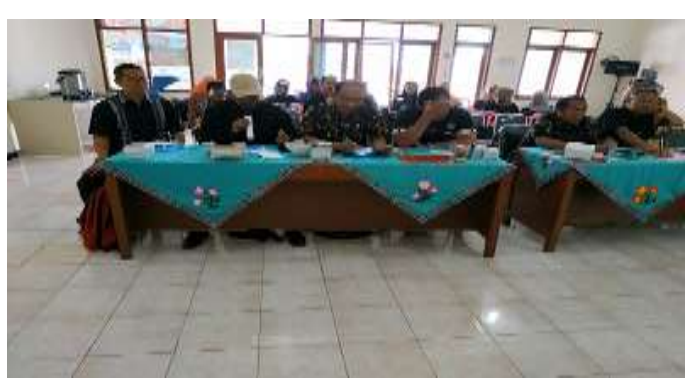

Gambar 2. Peserta mengikuti sosialisasi pajak

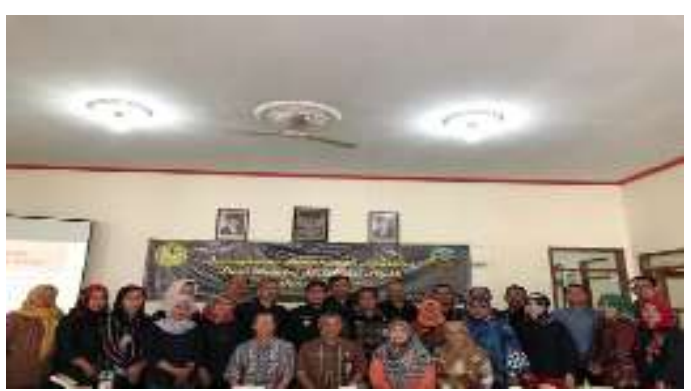

Gambar 3.Seluruh peserta sosialisasi pajak atas pengadaan barang dan jasa

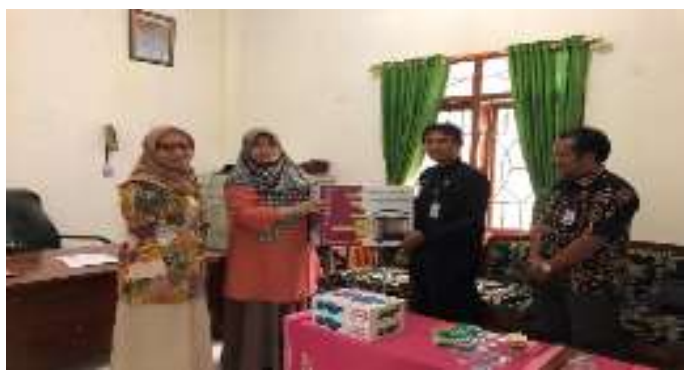

Gambar 4. Pemberian cenderamata pada Mitra PKM berbasis Riset 


\section{KESIMPULAN}

Pajak telah menjadi bagian dari pendapatan negara yang dimanfaatkan untuk kepentingan membangun negara. Demikian pula pada dana desa tak luput dari obyek yang dikenakan pajak. Nilai dana desa yang besar dan tersebar di seluruh wilayah Indonesia menjadi sangat penting untuk dikelola. Namun, terkait dengan perpajakan dana desa, mayoritas masih banyak terdapat aparatur desa yang belum sepenuhnya memahami mekanisme penghitungan pajak terkait dana desa. Observasi yang dilakukan pada desa-desa di Kecamatan Sumbang Kabupaten Banyumas, tercatat dari seluruh pertanyaan hanya mampu dijawab rata rata sebesar $40 \%$ saja. Dengan demikian sosialisasi terkait pajak dana desa menjadi penting untuk dilakukan dalam mengatasi masalah tingkat pemahaman aparatur desa terkait pajak yang masih rendah. Peningkatan pemahaman aparatur desa meningkat menjadi $84 \%$ setelah dilaksanakan sosialisasi tersebut. Sehingga sosialisasi atas perpajakan perlu dilaksanakan secara berkelanjutan, dengan mempertimbangkan bahwa ketentuan perpajakan sering kali mengalami perubahan yang cepat.

\section{UCAPAN TERIMAKASIH}

Terimakasih kami ucapkan sebesarbesarnya kepada LPPM Unsoed yang telah memberikan kepercayaan kepada Tim Pengabdi FEB Unsoed untuk melaksanakan PKM berbasis Riset yang didanai dari dana BLU PT tahun anggaran 2018/2019. Tak lupa kepada seluruh mitra pengabdian yaitu para aparatur desa di Kecamatan Sumbang, Kabupaten Banyumas.

\section{DAFTAR PUSTAKA}

Bichler, M. (2013). Procurement for Local Development; A Guide to Best Practice in Local Government Procurement in Least developed countries. UN Capital Development Fund 2013..

BPS 2018. Kabupaten Banyumas dalam Angka.

Huka, H.A., Mchopa, A.D. and Kimambo, J.J. (2014) .Analysis of procurement procedures in local government authorities: experience after procurement reforms and case analysis from selected councils in Kilimanjaro Tanzania, European Journal of Business and Management, Vol. 6, No. 18, pp.16-22.

Katadata.co.id. 2017. Setoran Pajak Bendahara Pemerintah Seret, Pengawasan Bakal Diperketat. 12 September 2017. Diakses di https://katadata.co.id/berita/20 17/09/12/setoran-pajakbendahara-pemerintahseretpengawasan-bakaldiperketat. Pada tanggal 27 Agustus 2019.

Ki-moon, B. (2012). Transparency and public procurement, in local government authority. Supplement to the 2011 Annual Statistical Report on United Nations Procurement.

Odhiambo, W. and Kamau, P. (2003). Public Procurement: Lessons from Kenya, Tanzania and Uganda available online at http://www.oecd.org/data oecd /59/11/2503452.pdf retrieved on 10.09 .2019

Permendes PDT. 2018, Nomor 16 tentang Prioritas Penggunaan Dana Desa. 